\title{
Anonymity and Individuation in the Nouveau roman
}

\author{
Lois Oppenheim \\ (Montclair State College, New Jersey)
}

In accord with the dichotomizing tendency of New Novel criticism over the years -- that criticism which, from the start, sought meaning either on the order of objectifying description characterized by photographic presentation and the absence of narrative commentary or on the order of the subjectivation of the object by a perceiving consciousness -- it is tempting to view the most recent efforts of those writers commonly associated with the Nouveau Roman in terms of a repossession of the individual that would contrast neatly with the anonymity of the fictive personages of the early works. The individual in question, of course, would bear no greater resemblance to the character of old than Beckett's Unnameable or Robbe-Grillet's Voyeur insofar as he or she would represent not modes of adherence to or defiance of a given social order, but the imaginative reshaping of otherwise repressed aspects of the author's own empirical existence. At once autobiography and fiction, these works would be viewed as offering an inventive solution to the transcendental neutrality, to the metaphysical anonymity that incarnated the New Novelist's research on characterization in the 1950s and 1960s. It is our opinion, and it will be the purpose of this essay to prove, however, that to locate in the individuation effected through the combined efforts of remembrance and fictive creation an antidote to the effaced subject is both to impede any real insight into the fundamental relation of anonymity and individuation that, then as now, is characteristic of this literature and to succumb, once again, to the reductive polarizing that diverted early New Novel criticism from the unveiling of the ontological dimensions and precategorical, and hence pre-symbolic structures that might have been its focus.

We would argue that any movement toward the individuation of a subject in the recent texts of certain of the New Novelists constitutes less a movement away from anonymity than a revalorization on the part of these novelists of the function of perception in the creative process. This view is supported by the notion that the text is above all a disclosure of our historical or temporal existence, a notion to which the New Novelists' autobiographical fiction of

LittéRéalité, Vol. I, No. 1, Printemps/Spring 1989 
recent years attests both creatively - on the level of the story, at once true and fictive - and cognitively - in the authors' efforts to come to terms with a discourse of remembrance. A necessarily brief look at the temporality at work in two of these texts, Nathalie Sarraute's Enfance and Claude Simon's L'Invitation, should (1) reveal that the fictive element is an unavoidable derivative of the objectifying focus on the past and (2) substantiate the premise that the interrelation of anonymity and individuation is dialectical as opposed to dichotomous and, hence, that the augmentation of the latter in no way implies a mere minimalization of the former.

In its early years, the New Novel represented the first step toward the liberation of the reader from a unifying novelistic aesthetic, from an epistemological positivism rooted in the privileged referentiality of fiction to the bourgeois values of the quotidian world. In its second stage, this fiction became linked, through the ensemble of theoretical formulations surrounding it (in the late 1960s and 1970s), with the antireferential motif that sought to abstract narrative realism from its perceptual ties with the world and to resituate it on the level of its mechanical construction. In recent years, the Nouveau Roman and the kind of realism that defines it no longer centers either on the exploration of knowledge of the objective world through the relation of subject and object in perception or on the reduction of that relation to the linguistic structures that are the text. Rather, a new referential framework, an historical one, has supplanted the earlier existential focus on temporality as a continuous present. And it is precisely in this historical context that individuation-and the autobiographical reconstitution of past experience that counters the pull toward anonymity or effective neutrality -is revealed as the source or origin of the effective element.

In Enfance, for example, the most authentically autobiographical of the New Novelists' recent writings, the fictive element derives neither from a simple departure from realism into fantasy or from a Proustian post-perception stream of consciousness, but from the inability of consciousness to perceive the world outside of its own participation in it as well as from the obliterating force of the temporal distance in question. This is to say that the fiction resides in a necessarily modified reconstitution of a pre-linguistic sensibility what is, in essence, the objectivation of a pre-cognitive awareness - distorted (an in this sense made fictive) by the participation of a present subjectivity in past experience. Words, in Enfance, in contrast to the perceptions or sensations that exist prior to them, also serve to fictionalize in the sense that 
naming, in this work, falsifies reality to the degree that it concretizes, in an adult vocabulary, the child's experience outside of the child's perception.

In all three of the fictionalizing processes - the revitalization of the past (1) through the projection onto it of a consciousness perceptualizing in the present, (2) through a memory weakened by time and (3) through the falsifying verbal fixing or labeling of experience - it is the will to objectify, one that translates into a struggle for individuation (or the differentiation of self) against an identification of self with the anonymity or universality of Being, that is the point of departure. We have only to consider the number of names attributed to her throughout her childhood to understand (in part) the author's motivation: From Natacha to Tachok to Nathalie, from the stepmother's heavily accented N't'che to the father's persistent "ma fille, ma petite fille, mon enfant" (at once an affirmation of the particular familial relation that bound them and a reminder of the challenge this relation represented), 1 each name delineates, both for the reminiscent novelist and her reader, otherwise anonymous subjectivities whose characterizations are characterizations only within the context of their objectivation by naming, only, in other words, within the context of one subjectivity's existence as an object for another subject.

And yet, never does individuation win out over anonymity, or even position itself dichotomously against it, for the intrusions of a less emotionally invested interlocutor, on the one hand, and the simultaneous opening of Sarraute's use of language onto the temporal horizons of past and present, on the other, contribute to a dialectical totality effected through the alternation of them. With regard to the first, it is precisely this splitting of language into two voices that allows for what amounts to a partial deconstruction of the individuation process. Through the distancing of the author from herself that the dialogue in and of itself achieves, the individuating process is undone. This, of course, nourishes the fictionalization of reality that renders Sarraute's work of particular interest above and beyond the more typical autobiographical portrait. (And in the context of this fictionalization, we might note, first, the metaphorization of the Cinderella tale implicated by Sarraute's recounting of her childhood and, second, the evocative naming of Natacha's half-sister. It is significant that not only is this child not given her own name [she is named for the deceased infant that would have been her other half-sister], but that she is not called either by the name given her, Hélène, or by the name the author's mother supposed she would have been given, Lola ${ }^{2}$ - both of which bring to the fore, once again, the complexities of the relation of identification to individuation and the notion that 
individuation in Sarraute is accomplished only in accordance with the multiple identities of a subject objectified for numerous subjectivities.)

With regard to the simultaneous opening of Sarraute's language onto the horizons of past and present, that which further prevents any minimalization of anonymity in favor of individuation, it is precisely the temporality of perception, the temporality of objectivation - a temporality at once retrospective and prospective, retentive and protentive - that allows the individuating process to develop. We have only to consider what is perhaps the most emotionally convulsive moment in the book - when the young Natacha's father reveals her mother's betrayal of her confidence, her mother's revelation to her former husband of the child's unhappiness in his home - to see how the entire evocation of the past is constructed according to this temporal complementarity:

... Je ne sais pas exactement ce que mon père sentait, mais moi, à cet âge-là, je n'avais pas neuf ans, je suis sûre que tout ce qui petit à petit s'est révélé à moi, au cours des années qui ont suivi, je l'ai perçu d'un coup, en bloc ... tous mes rapports avec mon père, avec ma mère, avec Véra, leurs rapports entre eux, n'ont été que le déroulement de ce qui s'était enroulé là. 3

[ . . . I don't know exactly what my father felt, but I, at that age, I wasn't yet nine, I am sure that all that little by little was revealed to me over the years that followed, I perceived at once, as a whole ... all my relationships with my father, with my mother, with Véra, their relationships with each other, were but the unwinding of what was wound up there.]

The absence of any artificial linking of events in Enfance - a linking that would introduce a causality, a predeterminism ${ }^{4}$ antithetical to Sarraute's entire aesthetic-stems from the kind of protentive-retentive temporal movement described above. And indeed, the entire transformation of the child - what Aline Baehler, in an article entitled "Véra, ou la voie de la normalisation, refers to as a metamorphosis effected "sous le carcan de l'uniformisation" 5 - is dependent upon this temporalization process: Reality, in Enfance, is repeatedly constructed on a fictive foundation which, in turn, is a construct deriving from the real - and this, ad infinitum. The revelation of the mother's betrayal of her daughter's confidence is but one example of the disintegration of a reality erected on a fictive foundation, in this case that of Natacha's assumption of her mother's loyalty. Indeed, the entire narrative 
reveals a young girl's living out of a fictive, Cinderella-like relation to a wicked step-mother whose ultimate humanization, 6 or defictionalization, is achieved retentively - in retrospective cognition through objectivation - and protentively - in the narrative revitalization of experience.

If, in Enfance, the interrelation of fiction and reality seems to reside within an objectified de-composition and re-composition of the past achieved through a simultaneously retentive and protentive temporality, in L'Invitation this interrelation appears to reside in the evocation of an experiential state located, by virtue of Simon's unique descriptive devices, outside of any linear temporal framework. Simon's recounting of his visit with some fourteen other guests to the Soviet Union is a somewhat amusing commentary on flagrant if naïve propagandizing. A reading of this text, however, which would resist interpretation according either to thematization (that which leads more to a closure of than an opening onto the Simonian descriptive processes) or to the symbolist game that consists in locating within the fictive realization references to the ethical or ideological convictions that inform it would appear to reveal a temporality both regressive and originary that is perhaps more apprehensible in terms of a pre-historical than an historical context.

L'Invitation is the narrative of interminable speeches never spoken before the reader, the narrative of limitless dialogues never articulated for the reader, the narrative of innumerable verbalizations never verbalized, this by virtue of the descriptive expression privileged by Simon. It is, moreover, the narrative of communication in foreign (which is to say incomprehensible) languages and of communication between persons responding to "un fleuve de paroles par un autre fleuve de paroles,"7 [a river of words by another river of words], a communication subversively mirrored in the interminable linking, the unceasing flow of the words we are reading, words having for subject a discursive and virtually unarticulated language that remains the thematic sine qua non of the novel. It is precisely by the rhythm of these incantatory sentences generating paradigmatically and syntagmatically unexpected and originary forms that the reader experiences a sort of temporal regression to a pre-historical or supra-historical time that achieves the decomposition of the narrative thread noted in Sarraute as well. This is to say that the delineation of the lived experience, the revitalization of the visit to Russia -- and hence the individuation of a perceptualizing consciousness or an effective subjectivity -- generates, through the suspension of any fundamental interaction between individuals, through the suspension of any ideological taking of sides, through the suspension of any influence or power 
of one individual over another, all accomplished through the absence of dialogue, the absence of the very communication described a field of neutrality in which anoymity reigns.

Otherwise stated, Simon's text erects a fictive world not through the discursive re-presentation or objectivation, but the poetic sur-realization of the memory. This is evident from the beginning of the novel where we read:

D'ordinaire (c'est-à-dire depuis leur arrivée dans le pays, dix jours auparavant) on les véhiculait, chacun accompagné de son interprète, dans une voiture particulière ... 8

[Ordinarily (that is to say since their arrival in the country ten days earlier) they were driven, each accompanied by his interpreter, in a special car...]

From the start the reader perceives the startling contrast between the thematic affirmation --"Ordinarily ... they were driven in a special car" -- and the enigma of the characters' identity -- " ... since their arrival... they were driven..." This distinction between the designative phrase, communicative on the order of referential and logical certainty, and the use of the personal pronoun produces a sort of rupture, a decomposition that serves to negate the order of meaning that would normally constitute an access to the verbal imagery. The uncertainty posed by the third person pronouns breaks the temporal flow, as well as the thematic tranquility, by a dispersion of implied interrogation: To whom do these pronouns refer? Why are these anonymous persons in this country, it being anonymous as well? Where do they go so routinely in this car? And so on.

This irruption of anonymity at the center of the realistic edifice in the process of being constructed by the logical and representational thinking of the reader does not cease to disturb, to shake the textual unity: The use of the pronoun "they," for example, is followed throughout the entire text by the parenthetical bracketing of "the fifteen guests," that which interrupts the syntactic construction as much as it displaces -- by the reintroduction of the anonymity of the personages, an anonymity underscored by the vague appellation "fifteen guests" -- the signifying totality. Individuation does offset this anonymity -- at once the reflection of the primordial universality of the existentialist's Being-in-the-world and the attraction to the archetype characteristic of Simon -- but never do the individualizing precisions succeed in fixing characterization outside of the anonymity/individuation dialectic. 
The two chiefs of state are individuated as men who have the ability to destroy half the earth or as actors one of whom

avait accédé à cette fonction non en vertu de capacités ou de connaissances spéciales mais à force de galoper sur un cheval, coiffé d'un chapeau de cow-boy et souriant de toutes ses dents dans des films de troisième catégorie ...9

had achieved this function not by virtue of particular capabilities or knowledge but by galloping on a horse, dressed with a cowboy hat and smiling broadly in third-rate films...]

The other personages are individuated either through textual digressions that are fundamentally temporal regressions toward predecessors of one type or another or through the mention of diverse capabilities or nationalities. Always, however, there is an immediate return to universality, primordially to the archetype, to, in other words, anonymity and, hence, to the uncertainty and interrogation that Lucien Dällenbach has termed, in a recent essay on Simon, "la question primordiale." 10

Anonymity also plays a fundamentally ontological role in Simon's novel to the extent that the novelist's repetitive and elliptic descriptive structures dramatize the experience of being -- by way of l'invitation-suspended out there. Both the telluric image of the "vieille et monstrueuse montagne" [old and monstrous mountain] and the acquous image of the forever invisible, but nontheless audible torrent serve as leitmotivs orienting the reader toward the fifteen invited personages' precognitive or non-positional awareness of them. As such, they metaphorically reveal both an hors-lieu -- that of the experiential state of being elsewhere (outside one's proper milieu, outside one's own country, beyond the familiar) -- and an hors-temps -- that of the experience of waiting (for departures, meetings, ceremonies). In this way, the text posits, in the context of the official visit which enframes the novel, the experiential situation of being invited. By a continuously regressive temporality, by a temporal decomposition that results in a mise en abîme of the fiction, by the suspension of an historical progression that would be comprehensible only in accordance with representational thinking, with the absence of any significant identification of the text with a pre-existing reality, Simon's reader bears witness to the dramatic replacing of the narrative event by the textual advent -- which is to say that the text unveils, in terms of a dialectical and hence temporal movement between anonymity and individuation, a fictive restoration of a lived experience. 
In conclusion, we state the following: Unlike in Proust, where the focus on the past results in a sensitizing of memory, objectivation in Sarraute and surrealization in Simon are the aesthetic registers that, in the two works in question, fictionalize autobiography. In Sarraute, it is a reality, such as that of the birth of Verra's daughter Lili, that unleashes the fantasy which, in turn, serves as the foundation for the structuring of another reality. In Simon, it is an existentializing of a reality (the visit to the Soviet Union) - an existentializing achieved through fractured syntax, regressive imagery, fragmented thematization -- that establishes a fictive world originary or generative in its surpassing of one constituted a priori. In both, however, it is within the framework of the interrelation of anonymity and individuation -a dialectical and therefore temporal interplay -- that the author explores, on the level of the characterization of self, the very same question that, in earlier works of these and other Nouveaux Romanciers, was posed on the level of the characterization of the other: If the early Nouveau Roman represented an exploration within the novel itself of the function of character in a fictionalized world, it also represented an investigation of the interplay of an internalized image of author with an authorial self-image that preceded it. The more recent writings of the New Novelists focus still on this confrontation of ambiguously delineated selves, this doubling of the authorial I, although the continuity of the preoccupation is somewhat veiled, in the autobiographical fiction characteristic of these latest texts, by a positing of the past as the origin of the fictive element. In essence, the New Novelist, to cite Robbe-Grillet, "writes against himself," in the Sartrean sense of the term, and hence against the public as well, 11 as a result of a profoundly paradoxical relation both to the world and to him or herself, one that for Robbe-Grillet is necessarily "double, contradictory and fleeting."12 And thus the anonymity/individuation dialectic remains forever incomplete, falling short, in the recent as in the early Nouveau Roman, of resolution -- for, in the words of Rimbaud, "Je est un autre."

* I am extremely grateful to the Montclair State College Career Development Fund for its generous support of this project.

1 Natalie Sarraute, Enfance (Paris: Gallimard, 1983), 251.

2 Ibid., 236. 
3 Ibid., 113. (Translated by us.)

4 Aline Baehler, in "Véra ou la voie de la normalisation," n.d., n.p., (publication forthcoming), sees the re-organization of the fragmented memories and unlinked sequences precisely in terms of the emotional investment and metamorphosis of the step-mother by the child. Hence, for Baehler, a predeterminisn does exist in Enfance on the level of latent psychological drives. She is quick to point out, however, that these are implicit in the work and do not constitute any sort of unifying aesthetic structure.

5 Ibid.

6 This humanization of the step-mother must be seen in both the context of a de-mythologizing of the Cinderella metaphor and that of the normalization of the child that Baehler so intelligently unveils in the essay cited above.

7 Claude Simon, L'Invitation (Paris: Minuit, 1987), 65. (Translated by us.)

8 Ibid., 9.

9 Ibid., 13.

10 Lucien Dällenbach, "La Question primordiale," in Sur Simon (Paris: Minuit, 1987).

11 Alain Robbe-Grillet, Le Miroir qui revient (Paris: Minuit, 1984), 40.

12 Ibid., 41. (Translated by us.) 